\title{
ANALISIS PELAKSANAAN KURIKULUM 2013 PADA PEMBELAJARAN PENDIDIKAN AGAMA ISLAM DAN BUDI PEKERTI DI SMA NEGERI 1 KOTA SOLOK
}

\author{
Rahmad Azuwardi \\ Guru Pendidikaan Agama Islam SMA Negeri 3 Kota Solok \\ e-mail: rahmadazuwardi@ymail.com
}

\begin{abstract}
The problem in this research is not yet revealed Planning, Implementation and Evaluation of learning by teacher of PAI and Budi Pekerti on competency aspect of spiritual attitude and social attitude based on Permendikbud No. 22 of 2016 in SMA Negeri 1 Kota Solok. The purpose of this study is to Describe the planning, implementation and evaluation of learning PAI and Budi Pekerti viewed from the spiritual attitude and social attitude based on Permendikbud. 22 and 23 in 2016 in SMA Negeri 1 Kota. This research is qualitative research with research type field research. Sources of data in this study are teachers of Islamic Education and Budi Pekerti, principals and other data sources. Data collection techniques used were interviews, observation and documentation. The results obtained in the field consist of general findings and specific findings. General findings relate to school history and profile whereas specific findings related to planning are the development of the K13 syllabus of the Province then the teacher develops the indicators at the time of the PAI teacher's teacher at SMAN 1. but KKG PAI teachers did not go well. The newest RPP model made only one KD or one meeting only. RPP developed in accordance with the existing culture in the environment, the implementation of the allocation of time face-to-face learning 35 minutes. and Number of study groups 46 rombels. maximum number 36 Rombel, Textbook lessons have not been in accordance with the needs of learners. And evaluation of learning PAI and Budi Pekerti viewed from the spiritual attitude and social attitudes. Cognitive, affective and psychomotor appraisal books are too late to make. direct observation during the learning and supporting factors for teachers in the implementation of learning by teachers PAI and Budi in SMA Negeri 1 Kota Solok.
\end{abstract}

Keywords: Planning Curriculum 2013 on Learning Islamic Religious Education and Character in SMA Negeri 1 Kota Solok.

\section{PENDAHULUAN}

Pelaksanaan pendidikan di Indonesia diharapkan mampu membentuk manusia Indonesia yang memiliki kepribadian yang luhur, hal ini sesuai dengan Peraturan Menteri Pendidikan Nasional Nomor 22 Tahun 2006 Bab II tentang Standar Isi untuk satuan pendidikan dasar dan menengah, Pendidikan Agama Islam dimaksudkan untuk meningkatkan 
potensi spritual dan membentuk peserta didik menjadi manusia yang beriman dan bertaqwa kepada Tuhan Yang Maha Esa serta berakhlak mulia. Akhlak mulia mencangkup etika, budi pekerti atau moral sebagai perwujudan dari pendidikan agama (Permendikbud, 2006: 22).

Pembelajaran aktif, kreatif, inovatif, efektif, produktif, dan menyenangkan merupakan bagian dari kebijakan penyusunan Kurikulum 2013, tetap mengacu kepada fungsi Pendidikan Nasional sebagai arah dan tujuan pembelajaran, yaitu mengembangkan potensi peserta didik agar menjadi manusia yang beriman dan bertakwa kepada Tuhan Yang Maha Esa, berakhlak mulia, sehat, berilmu, cakap, kreatif, mandiri, dan menjadi warga yang demokratis serta bertanggung jawab (Pasal 3 UU Sisdiknas. 2003).

Pembelajaran adalah kegiatan dimana guru melakukan peran-peran tertentu agar siswa dapat belajar untuk mencapai tujuan pendidikan yang diharapkan. Terdapat berbagai konsepsi tentang pembelajaran, hal ini dapat terjadi karena adanya perbedaan pendapatan yang digunakan orang dalam memahami makna pembelajaran ( Mulyasa, 2014: 132). Proses pembelajaran, selain untuk mengatasi dan mencegah penurunan nilai-nilai moral, sikap yang dimiliki peserta didik juga dapat meningkatkan prestasi peserta didik dan peningkatan sikap serta perilaku positif dari peserta didik akan berdampak positif juga pada nilai akademik. Oleh karena itu, suatu lembaga pendidikan diharapkan dapat meningkatkan peranannya terutama dalam pembentukan kepribadian peserta didik melalui penilaian sikap dalam pembelajaran dikelas.

Mata pelajaran Pendidikan Agama Islam dan Budi Pekerti merupakan salah satu mata pelajaran yang diwajibkan untuk menilai KI-1 dan KI-2 yang merupakan penilaian aspek sikap, agama, dan moral. Para pendidik, khususnya para pendidik mata pelajaran Pendidikan Agama Islam dan Budi Pekerti sehingga sangatlah perlu untuk memahami dan mengerti tentang aspek penilaian sikap yang ada dikurikulum 2013 (Permendikbud, 2016: 20).

Berdasarkan wawancara dengan guru SMAN 1 Kota Solok, kemampuan spiritual dan kemampuan sosial anak di sekolah ada yang menengah dan ada juga yang sudah melupakan nilai spiritual tetapi tidak beberapa persentase kirakira di dalam lokal ada satu atau dua orang siswa. Pengalaman agama, dilihat disaat pelaksanaan shalat Dzuhur berjamaah di Masjid tidak menjadi kewajiban baginya, bahkan guru agama sudah gigih menyuruh shalat dan shalat berjamaah juga belum terlaksana dengan baik. 
Guru agama membuat absen shalat bagi siswa yang mana setiap akan shalat diabsen terlebih dahulu oleh sekretaris lokal masing-masing. laki-laki dan perempuan semuanya hampir sama susahnya disuruh melakukan shalat. Mulai dari tahun 2013 sikap dan kemampuan spiritual anak minim sekali kalau dilihat dilokal anak yang bagus akhlaknya sekitar 5 orang selebihnya menengah kebawah. Dan sudah 2 periode tes seleksi penerimaan siswa baru di sekolah, tidak dilakukan tes baca AlQur'an padahal melalui tes mengaji tercermin siswa menerapkan nilai keagamaan di rumah atau tidak menerapkan nilai keagamaan. (Wawancara Pribadi, Okti Suryani, Tgl 18 Mei 2017)

Masalah berikutnya adalah tingkah laku yang ingin mendapat perhatian orang lain oleh beberapa orang siswa seperti bernyanyi-nyanyi, peragaan main gitar, memukul-mukul meja, bercanda dengan teman dan mengganggu teman sebelahnya sehingga membuat suasana kelas menjadi gaduh. Masih banyak siswa yang terlambat datang ke sekolah, saat acara kegiatan keagamaan setiap hari Jum'at pagi. Adanya siswa yang duduk di warung saat kegiatan keagamaan pagi hari jum'at. Kurangnya perhatian dan dukungan oleh warga dan pemilik warung sekitar terhadap keterlambatan siswa dan siswa yang merokok. Masih adanya siswa yang tidak membawa al-Qur'an saat "tadarrus" di pagi hari. Masih sedikitnya siswa yang melaksanakan shalat berjamaah saat shalat dzuhur di sekolah.

\section{KONSEP DASAR KURIKULUM 2013}

Kurikulum adalah sejumlah mata pelajaran yang harus ditempuh dan dipelajari oleh siswa untuk memperoleh sejumlah pengetahuan (Hamalik, 2014: 16) Secara etimologis, istilah kurikulum (curriculum) berasal dari bahasa Yunani, yaitu curir yang artinya "pelari" dan curere yang berarti "tempat berpacu". Pada awalnya, istilah kurikulum berasal dari dunia olah raga, terutama dalam bidang atletik pada zaman Romawi Kuno di Yunani. Dalam bahasa Latin, kurikulum berasal dari kata currere yang berarti berlari (running) sebagai suatu pengalaman hidup.

Kurikulum berarti suatu jarak yang harus ditempuh oleh seorang pelari dari garis start sampai dengan garis finish untuk memperoleh medali atau penghargaan. Jarak yang harus ditempuh tersebut kemudian diubah menjadi program sekolah dan semua orang yang terlibat di dalamnya. Program tersebut berisi mata pelajaran-mata pelajaran yang harus ditempuh oleh peserta didik selama kurun waktu tertentu, seperti SD/MI (enam tahun), SMP/MTs (tiga tahun), 
SMA/SMK/MA (tiga tahun), dan seterusnya.

\section{LANDASAN KURIKULUM 2013}

Landasan filosofis dalam pengembangan kurikulum menentukan kualitas peserta didik yang akan dicapai kurikulum, sumber dan isi dari kurikulum, proses pembelajaran, posisi peserta didik, penilaian hasil belajar, hubungan peserta didik dengan masyarakat dan lingkungan alam di sekitarnya.

Landasan Teoritis Kurikulum 2013 dikembangkan atas teori "Pendidikan berdasarkan standar" (standardbased education), dan teori kurikulum berbasis kompetensi (competency-based curriculum). Pendidikan berdasarkan standar menetapkan adanya standar nasional sebagai kualitas minimal warganegara yang dirinci menjadi standar isi, standar proses, standar kompetensi lulusan, standar pendidik dan tenaga kependidikan, standar sarana dan prasarana, standar pengelolaan, standar pembiayaan, dan standar penilaian pendidikan. Kurikulum berbasis kompetensi dirancang untuk memberikan pengalaman belajar seluas-luasnya bagi peserta didik dalam mengembangkan kemampuan untuk bersikap, berpengetahuan, berketerampilan dan bertindak (UU No.20 Tahun 2003).

Landasan yuridis Kurikulum 2013 adalah:
1) Undang-Undang Dasar Negara Republik Indonesia Tahun 1945;

2) Undang-undang Nomor 20 Tahun 2003 tentang Sistem Pendidikan Nasional;

3) Undang-undang Nomor 17 Tahun 2005 tentang Rencana Pembangunan Jangka Panjang Nasional, beserta segala ketentuan yang dituangkan Rencana Pembangunan Jangka Menengah Nasional; dan

4) Peraturan Pemerintah Nomor 19 Tahun 2005 tentang Standar Nasional Pendidikan sebagaimana telah diubah dengan Peraturan Pemerintah Nomor 32 Tahun 2013 tentang Perubahan Atas Peraturan Pemerintah Nomor 19 Tahun 2005 tentang Standar Nasional Pendidikan (UUD 1945 alinia IV dan pasal 31)

\section{STANDAR PROSES MENURUT PERMENDIKBUD NOMOR 22 TAHUN 2016}

\section{Standar Perencanaan Pembelajaran Kurikulum 2013}

Perencanaan pembelajaran dirancang dalam bentuk Silabus dan Rencana Pelaksanaan Pembelajaran (RPP) yang mengacu pada Standar Isi. Perencanaan pembelajaran meliputi penyusunan rencana pelaksanaan pembelajaran dan penyiapan media dan sumber belajar, perangkat penilaian pembelajaran, 
dan skenario pembelajaran.

a. SD/MI : 35 menit

Penyusunan Silabus dan RPP

disesuaikan pendekatan

b. SMP/MTs : 40 menit

pembelajaran yang digunakan.

c. SMA/MA : 45 menit

Standar Pelaksanaan Pembelajaran

Kurikulum 2013

d. SMK/MAK : 45 menit

1) Persyaratan Pelaksanaan Proses

Pembelajaran

a) Alokasi Waktu Jam Tatap Muka

Pembelajaran

b) Rombongan belajar

Jumlah rombongan belajar per satuan pendidikan dan jumlah maksimum peserta didik dalam setiap rombongan belajar dinyatakan dalam tabel berikut:

Tabel 1

Rombongan Belajar

\begin{tabular}{|c|l|c|c|}
\hline No & Satuan Pendidikan & $\begin{array}{c}\text { Jumlah } \\
\text { Rombongan } \\
\text { Belajar }\end{array}$ & $\begin{array}{c}\text { Jumlah } \\
\text { Maksimum } \\
\text { Peserta Didik Per } \\
\text { Belajar }\end{array}$ \\
\hline 1. & SD/MI & $6-24$ & 28 \\
\hline 2. & SMP/MTs & $3-33$ & 32 \\
\hline 3. & SMA/MA & $3-36$ & 36 \\
\hline 4. & SMK & $3-72$ & 36 \\
\hline 5. & SDLB & 6 & 5 \\
\hline 6. & SMPLB & 3 & 8 \\
\hline 7. & SMALB & 3 & 8 \\
\hline
\end{tabular}

c) Buku Teks Pelajaran

Buku teks pelajaran digunakan untuk meningkatkan efisiensi dan efektifitas pembelajaran yang jumlahnya disesuaikan dengan kebutuhan peserta didik.

d) Pengelolaan Kelas dan

Laboratorium

2) Pelaksanaan Pembelajaran
Pelaksanaan pembelajaran merupakan implementasi dari RPP, meliputi kegiatan pendahuluan, inti dan penutup.

a) Kegiatan Pendahuluan

menyiapkan peserta didik secara psikis dan fisik untuk mengikuti proses pembelajaran, memberi motivasi belajar peserta didik secara kontekstual sesuai manfaat dan aplikasi materi ajar 
dalam kehidupan sehari-hari, dengan memberikan contoh dan perbandingan lokal, nasional dan internasional, serta disesuaikan dengan karakteristik dan jenjang peserta didik mengajukan pertanyaanpertanyaan yang mengaitkan pengetahuan sebelumnya dengan materi yang akan dipelajari.

b) Kegiatan Inti

Kegiatan inti menggunakan model pembelajaran, metode pembelajaran, media pembelajaran, dan sumber belajar yang disesuaikan dengan karakteristik peserta didik dan mata pelajaran. Pemilihan pendekatan tematik dan /atau tematik terpadu dan/atau saintifik dan/atau inkuiri dan penyingkapan (discovery) dan/atau pembelajaran yang menghasilkan karya berbasis pemecahan masalah (project based learning) disesuaikan dengan karakteristik kompetensi dan jenjang pendidikan.

c) Kegiatan Penutup

Dalam kegiatan penutup, guru bersama peserta didik baik secara individual maupun kelompok melakukan refleksi untuk mengevaluasi: (1)seluruh rangkaian aktivitas pembelajaran dan hasil-hasil yang diperoleh untuk selanjutnya secara bersama menemukan manfaat langsung maupun tidak langsung dari hasil pembelajaran yang telah berlangsung;

(2)memberikan umpan balik terhadap proses dan hasil pembelajaran;

(3)melakukan kegiatan tindak lanjut dalam bentuk pemberian tugas, baik tugas individual maupun kelompok; dan

(4)menginformasikan rencana kegiatan pembelajaran untuk pertemuan berikutnya.

\section{Standar Penilaian Pembelajaran}

\section{Kurikulum 2013}

1) Penilaian aspek sikap dilakukan melalui tahapan:

a) Mengamati perilaku peserta didik selama pembelajaran;

b) Mencatat perilaku peserta didik dengan menggunakan lembar observasi/pengamatan;

c) Menindak lanjuti hasil pengamatan; dan

d) Mendeskripsikan perilaku peserta didik.

2) Penilaian aspek pengetahuan dilakukan melalui tahapan:

a) menyusun perencanaan penilaian; 
b) mengembangkan instrumen penilaian;

c) melaksanakan penilaian;

d) memanfaatkan hasil penilaian; dan

e) melaporkan hasil penilaian dalam bentuk angka dengan skala 0-100 dan deskripsi.

3) Penilaian aspek keterampilan dilakukan melalui tahapan:
a) menyusun perencanaan penilaian;

b) mengembangkan instrumen penilaian;

c) melaksanakan penilaian;

d) memanfaatkan hasil penilaian; dan

e) melaporkan hasil penilaian dalam bentuk angka dengan skala 0-100 dan deskripsi.

Adapun definisi standar penilaian pendidikan dijelaskan dalam Lampiran Permen Nomor 66 Tahun 2013 tentang Standar Penilaian Pendidikan, adalah kriteria mengenai mekanisme, prosedur dan instrument penilaian hasil belajar peserta didik. Definisi tersebut juga senada dengan definisi standar penilaian pendidikan yang dijelaskan oleh E. Mulyasa (2009: 43).

\section{PENGERTIAN PEMBELAJARAN PAI DAN BUDI PEKERTI}

Belajar ialah suatu proses usaha yang di lakukan seseorang untuk memperoleh perubahan tingkah laku secara keseluruhan, sebagai hasil pengalamannya sendiri dalam interaksi dengan lingkungannya (Slameto, 2003: 2). Pembelajaran adalah penyediaan kondisi yang mengakibatkan terjadinya proses belajar pada peserta didik. Penyedian kondisi dapat di lakukan dengan bantuan pendidik (guru) atau di temukan sendiri oleh individu (belajar otodidak). Peristiwa belajar tidak selalu terjadi atas inisiatif diri individu. Individu memerlukan bantuan untuk mengembangkan potensi yang ada pada dirinya (Ridwan, 2013: 40).

Menurut Muhammad Abdul Qadir Ahmad tujuan Pendidikan Agama Islam adalah:

a. Meningkatkan kemampuan murid membaca al-Qur'an secara baik dan benar.

b. Mempererat hubungan murid dengan kitabullah sehingga meraka akan merasa indah dengan metode yang dipakai oleh al-Qur'an.

c. Menjelaskan maksud al-Qur'an tentang tanda-tanda kekuasaan Allah dan menganjurkan mereka mempelajari tentang sifat-sifatnya.

d. Membekali murid dengan berbagai ibadah, hukum-hukum agama dan problema-problema masyarakat agar agama dan ibadah mereka benar serta bermoral tinggi.

e. Menjelaskan bahwa Rasul berfungsi sebagai penafsir alQur'an. 
f. Menganjurkan kepada murid mengikuti jejak para sahabat dan pahlawan muslim yang shaleh dan merasa bangga atas kepahlawanan mereka. Hal tersebut membuat mereka berpegang kepada persatuan dan persaudaraan yang didasarkan kepada Islam.

g. Para murid agar menerapkan pelajaran ini dalam kehidupanya dan dalam berbagai kegiatan, baik kegiatan agama maupun kegiatan sosial (Qadir, 1985: 248).

\section{METODE PENELITIAN}

Jenis penelitian ini adalah penelitian lapangan ( field research), yakni penelitian yang deskriptif kualitatif, yaitu penelitian yang bertujuan menggambarkan secara sistematis mengenai fakta-fakta yang ditemukan dilapangan, bersifat verbal, kalimat-kalimat, fenomenafenomena, dan tidak berupa angkaangka (Moeleong, 2001: 6).

Metode penelitian dalam penelitian ini adalah kualitatif yaitu penelitian yang menghasilkan data deskriptif berupa kata-kata tertulis atau lisan dari orang-orang atau perilaku yang diamati (Moeleong, 2001: 3). Penelitian ini adalah penelitian di sekolah, yakni penelitian yang di lakukan langsung mengamati kegiatan Analisis pelaksanaan kurikulum 2013 pada pembelajaran Pendidikan Agama Islam dan Budi Pekerti ditinjau dari sikap spiritual dan sikap sosial untuk menggali dan meneliti data yang berkenaan dengan analisis pelaksanaan kurikulum 2013 pada pembelajaran pendidikan Agama Islam dan Budi Pekerti di SMA Negeri 1 Kota Solok. untuk memperoleh data yang akurat dalam penelitian ini maka penulis menggunakan instrumen pengumpulan data yaitu observasi, wawancara dan dokumentasi.

Data yang diperoleh dalam penelitian dianalisis dengan menggunakan model analisis data kualitatif menurut Miles dan Huberman dilakukan secara interaktif melalui proses data reduction, data display, dan verification (Sugiyono, 2005: 147). Teknik yang digunakan dalam menguji keabsahan data dalam penelitian ini, yaitu teknik triangulasi. Triangulasi adalah teknik pemeriksaan keabsahan data yang memanfaatkan sesuatu yang lain diluar data itu untuk keperluan pengecekan atau sebagai pembanding terhadap data itu (Sugiono, 2010: 178).

\section{HASIL PENELITIAN DAN PEMBAHASAN}

Perencanaan Pembelajaran oleh guru PAI dan Budi Pekerti pada Aspek Kompetensi Sikap Spiritual dan Sikap Sosial berdasarkan Permendikbud No 22 tahun 2016

Perencanaan pembelajaran dirancang dalam bentuk Silabus dan 
Rencana Pelaksanaan Pembelajaran (RPP) yang mengacu pada Standar Isi. Perencanaan pembelajaran meliputi penyusunan rencana pelaksanaan pembelajaran dan penyiapan media dan sumber belajar, perangkat penilaian pembelajaran, dan skenario pembelajaran. Penyusunan Silabus dan RPP disesuaikan pendekatan pembelajaran yang digunakan. (Sisdiknas, 2003. Nomor: 20)

Berdasarkan temuan penelitian di SMAN 1 Kota Solok bahwa Silabus dari Propinsi kemudian direvisi dan dikembangkan oleh guru mata pelajaran PAI dan Budi Pekerti yang ada di SMAN 1 Kota Solok. Kemudian guru masing-masing kelas, mengembangkan hasil revisi MGMP sesuai dengan tingkatan. Materi yang direvisi ada materi yang dipindahkan ke kelas satu ada dari kelas satu yang dinaikkan ke kelas dua, ada materi kelas dua naik ke kelas tiga, perubahan dengan alasan kelas satu dan dua lebih padat karena di kelas tiga banyak ujiannya. Adapun pengulangan-pengulangan materi tentang birruwalidayn. Kemudian di kelas 2 diulang kembali di akhir, pembelajaran dan disepakati oleh semua guru ada 3 guru disamakan persepsinya, contoh perilaku kompetitif taat aturan dan etos kerja. Materinya sama kemudian nanti soal yang diberikan sama. dan dalam membuat RPP adalah pengembangan dari silabus, materi di Kurikulum 2013 ada buku pegangan guru, ada buku siswa materinya sama namun di buku pegangan guru ada langkah-langkahnya.

Berdasarkan temuan penelitian dalam pembuatan RPP di SMAN 1 Kota Solok dibuat pada saat KKG oleh guru-guru PAI dan Budi Pekerti. Dalam pembuatan RPP isi dan model-model pembelajaran disesuaikan dengan silabus yang diinginkan agar tujuan pembelajaran tercapai, dalam pembuatan RPP satu tingkatan itu sama isinya dengan semua lokal walaupun berbeda gurunya, dan ada juga penambahan itu tergantung kreatif guru masingmasing dalam mengembangkannya.

Pelaksanaan Pembelajaran oleh Guru PAI dan Budi Pekerti pada Aspek Kompetensi Sikap Spiritual dan Sikap Sosial berdasarkan Permendikbud No 22 tahun 2016

Persyaratan Pelaksanaan Proses Pembelajaran Alokasi Waktu Jam Tatap Muka Pembelajaran SMA/MA 45 menit. dan Jumlah rombongan belajar per satuan pendidikan dan jumlah maksimum peserta didik dalam setiap rombongan belajar dinyatakan SMA/MA jumlah rombongan belajar dari 3 sampai 36 Rombel, dan jumlah maksimum peserta didik per rombongan belajar sebanyak 36 orang, Buku teks pelajaran digunakan untuk 
meningkatkan efisiensi dan efektifitas pembelajaran yang jumlahnya disesuaikan dengan kebutuhan peserta didik.

Berdasarkan

wawancara

dengan guru mata pelajaran PAI dan Budi Pekerti dan temuan penelitian dapat diambil kesimpulan bahwa Pelaksanaan pembelajaran PAI alokasi waktu pelajaran hanya 35 menit untuk satu jam pembelajaran. Sedangankan dalam permendikbud nomor 22 tahun 2016 alokasi waktu jam tatap muka pembelajaran sebanyak 45 menit, jam pembelajaran di SMAN 1 Kota Solok baru memadai kalau seandainya kelas 10 jadi pindah ke lokal yang baru. dan dalam pengambilan nilai bacaan Al Qur'an dan hafalan, dilaksanakan sore harinya karena 2 shif masuk jam setengah 7 lewat 10 (6.40) pulang 12.45. Buku agama sangat kurang hanya buku dari Erlangga dan Kementerian Pendidikan sehingga saya untuk mengajar membeli buku PR buku LKS dan buku yang lain dan sekarang siswa tidak boleh membeli buku, kalau siswa ingin buku maka dia yang membeli buku sendiri dan dalam satu lokal niat dan motivasi belajar siswa tidak sama.

Evaluasi Pembelajaran oleh Guru PAI dan Budi Pekerti pada Aspek Kompetensi Sikap spiritual dan Sikap Sosial berdasarkan Permendikbud No 23 tahun 2016
Berdasarkan hasil temuan tentang penilaian sikap siswa di sekolah dinilai dari pengamatan, dan penilaian untuk pengetahuan dan keterampilan tesnya dari tugas dan penampilan makalah kelompok dan kehadiran siswa, dan ketrampilan mengaji, kelas sepuluh mengaji lumayan dari pada kelas sebelas. Ada UH lisan ada juga tugas membuat portofolio dan ada juga membuat proyek membuat video yang direkam temanya sedang ceramah temannya.

Berdasarkan temuan penelitian bahwa penilaian sikap anak blangko penilaiannya, dinilai tiap hari setiap kali masuk, penilaian berkisar dari nol sampai 4, untuk penjumlahan nilai ada sistemnya yang akan dibuat oleh Tim TE (Tim Evaluasi) langsung dimasukkan nilai keluar hasilnya dan ini absennya baru siap dengan buku penilaiannya. sebelumnya ditulis di kertas biasa. Kalau tidak ada ini guru akan kewalahan karena salah masuk nilai hasilnya pun jauh dan kenyataannya data tidak valid kalau tidak baku penilaian ada penilaian buku tentang kognitif, afektif dan psikomotor setiap kali masuk lokal secara umum dipahami bahwa penilaian adalah memberikan suatu nilai terhadap suatu objek yang dilihat, dirasa, diamati dan sebagainya. (Nana Sudjana 2012: 3). 


\section{PENUTUP}

\section{Kesimpulan}

Dari penelitian yang penulis lakukan dapat disimpulkan bahwa :

Perencanaan Pembelajaran oleh Guru PAI dan Budi Pekerti pada aspek kompetensi sikap spiritual dan sikap sosial berdasarkan Permendikbud No 22 tahun 2016 di SMA Negeri 1 Kota Solok. Silabus K13 dari Propinsi Kemudian guru yang mengembangkan indikatornya, pengembangan indikator dikembangkan pada saat KKG guru PAI dan Budi Pekerti di SMAN 1 namun KKG guru PAI tidak berjalannya dengan baik. Model RPP terbaru yang dibuat hanya satu KD atau satu pertemuan saja. RPP dikembangkan sesuai dengan budaya yang ada di lingkungan sekitar.

Pelaksanaan Pembelajaran oleh guru PAI dan Budi Pekerti pada aspek kompetensi sikap spiritual dan sikap sosial berdasarkan Permendikbud No 22 tahun 2016 di SMA Negeri 1 Kota Solok. Persyaratan Pelaksanaan Proses Pembelajaran dari Alokasi Waktu Jam Tatap Muka Pembelajaran SMAN 1 Kota Solok 35 menit. dan Jumlah rombongan belajar 46 rombel. per satuan pendidikan dan jumlah maksimum peserta didik dalam setiap rombongan belajar dinyatakan SMA/MA jumlah rombongan belajar dari 3 sampai 36 Rombel, dan jumlah maksimum peserta didik satu rombongan belajar sebanyak 36 orang, Buku teks pelajaran digunakan untuk meningkatkan efisiensi dan efektifitas pembelajaran yang jumlahnya disesuaikan dengan kebutuhan peserta didik.

Pelaksanaan pembelajaran merupakan implementasi dari RPP meliputi kegiatan pendahuluan, inti dan penutup Ketika materi tentang ayat, anak belajar sendiri menghafal dan memahami mencari tajwid dan mencari ayat potongan mufradat dan lalu arti mufradat itu kalau satu ayat satu pertemuan dia kerjakan sendiri. Tetapi kalau seluruhnya disuruh memecahkan surat beserta tajwidya dicari dan mufradatnya dan sebagainya. Tugasnya bersifat portofolio untuk tugas semester, Materi yang menarik bersifat kompetitif itu tergantung video yang kuat stimulusnya dan penutup pembelajaran diberikan umpan balik terhadap proses pembelajaran, menyimpulkan, pemberian tugas dan menginformasikan rencana kegiatan pembelajaran untuk pertemuan selanjutnya.

Evaluasi pembelajaran oleh guru PAI dan Budi Pekerti pada aspek kompetensi sikap spiritual dan sikap sosial berdasarkan Permendikbud No 23 tahun 2016 di SMA Negeri 1 Kota Solok. Penilaian sikap anak ada KI 1, KI 2, KI 3 dan KI 4, dinilai setiap hari setiap kali masuk dan dimasukkan ke dalam blangko penilaian, Penilaian 
berkisar dari nol sampai 4, untuk penjumlahan nilai ada sistimnya yang akan dibuat oleh Tim TE (Tim Evaluasi) langsung dimasukkan nilai akan keluar hasilnya. Kalau tidak ada blangko penilaian guru akan kewalahan kalau tidak buku penilaian ada penilaian buku tentang kognitif, afektif dan psikomotor. Penilaian siwa membuat seperti membuat makalah kemudian tampil mempresentasikan dan nilai membuat rangkuman, dan catatan diperiksa dan ada UH dan pengayaan kemudian nilai keterampilan membaca ayat dan tugas lainnya. ambil nilai bacaan Al Qur'an, hafalan dilaksanakan sore hari karena jam pelajaran tidak cukup untuk melakukan penilaian siswa.

\section{Saran}

Berdasarkan pembahasan diatas, penulis dapat mengemukakan beberapa saran diantaranya :

1. Dalam rangka Perencanaan Pembelajaran oleh Guru PAI dan Budi Pekerti pada Aspek Kompetensi Sikap Spiritual dan Sikap Sosial Guru hendaknya bisa merencanakan pembelajaran secara keseluruhan agar tujuan pelajaran tercapai dengan baik.

2. Sebaiknya MGMP guru agama islam PAI dan Budi Pekerti untuk SMAN 1 Kota Solok dilaksanakan kembali supaya perencanaan pembelajaran bisa terlaksana dengan baik dan sesuai silabus.

3. Waktu pembelajaran PAI dan Budi Pekerti sebaiknya disesuikan dengan standar waktu pelajaran propinsi agar waktu cukup dan pembelajaran tercapai.

4. Diharapkan bagi semua siswa untuk selalu memanfaatkan waktu dengan sebaik-baiknya, serta selalu mengikuti tata tertib dan peraturan dengan seksama, dan juga disiplin serta rajin dalam menuntut ilmu.

\section{KEPUSTAKAAN ACUAN}

Abdullah Sani, Ridwan. 2013. Inovasi Pembelajaran. Jakarta: Bumi Aksara.

Ahmad, Muhammad Abdul Qadir. 1985. Metodologi Pengajaran Pendidikan Agama Islam. Jakarta: Proyek Pembinaan Prasarana dan Perguruan Tinggi Agama/IAIN.

Alghazali. 1993Mutiara Ihya Ulumuddin, Bandung: Mizan Pustaka.

Aly, Hery Noer. 199. Ilmu Pendidikan Islam. Jakarta: Logor Wacana Ilmu.

Amin, Ahmad. 1995. Etika (Ilmu Akhlak). Jakarta: Bulan Bintang.

Aminah, Siti. 2016. Evaluasi implementasi KI-1 dan KI-2 di SD Negeri Kota Yogyakarta. Jurnal Evaluasi Pendidikan (Online), 
Vol 4 (1), 8 halaman.

Tersedia:http://journal.student. uny.ac.id/ojs/index.php/jep

Anshari, Endang Syaifudin. 1993. Pokok-Pokok Pikiran Tentang Islam. Jakarta: Usaha Enterprise.

Halim, Mahmud Ali Abdul. 2004. Akhlak Mulia. Jakarta: Gema Insani Press.

Hamalik, Oemar. 2005. Proses belajar mengajar. Jakarta: Bumi Aksara.

Hamalik, Oemar. 2014. Kurikulum dan pembelajaran. Jakarta: Bumi Aksara.

Machsin. 1995. Menyelami Kebebasan Manusia (Telaah Kritis Terhadap Konsepsi Al-Qur'an). Yogyakarta: Pustaka Pelajar.

Moeleong, Lexy J. 2001. Metode Penelitian Kualitatif. Bandung: PT Remaja Rosdakarya.

Munawwir. 1997. Kamus ArabIndonesia. Surabaya: Progresif.

Qardhawi, Yusuf. 1980. Pendidikan Islam dan Madrasah Hasan AlBanna. Jakarta: Bulan Bintang.

Ramayulis. 1994. Ilmu Pendidikan Islam. Jakarta: Kalam Mulia.

Ridwan Abdullah Sani, Inovasi Pembelajaran, Jakarta, Bumi Aksara:2013

Sanjaya, Wina. 2006. Strategi Pembelajaran Berorientasi Standar
Proses Pembelajaran. Jakarta: Kencana Prenidia Group.

Shihab, M. Quraish. 1994. Wawasana Al-Qur'an-Tafsir Tematik atas Berbagai Persoalan Ummat. Bandung: PT Mizan.

Slameto. 2003. Belajar Dan FaktorFaktor Yang Mempengaruhinya. Jakarta: Rineka Cipta.

Sugiyono. MetodePenelitian Pendidikan Pendekatan Kuantitatif, kualitatif, dan RED. Bandung: Alfabeta, 2010

Ulfah, Humaira. 2015. Studi realitas Implementasi Kurikulum 2013 pada mata pelajaran PAI dan Budi Pekerti jenjang SMA (Studi Deskriptif pada Berbagai Klasifikasi Guru SMA di Kota Bandung tahun 2015). Jurnal Pendidikan.

Umary, Barmawi . 1989. Materi Akhlak. Solo: Ramadhani.

Yunus, Mahmud. 1983. Metodik Khusus pendidikan Islam. Jakarta: Hidakarya Agung.

Departemen Pendidikan dan Kebudayaan,1996. Kamus Besar Bahasa Indonesia. Jakarta: Balai Pustaka

E. Mulyasa, 2006, Implementasi Kurikulum 2013 Bandung: Remaja Rosdakarya.

E. Mulyasa, 2014, Kurikulum Tingkat Satuan Pendidikan, Sebuah Panduan Praktis Bandung: Remaja Rosdakarya. 
Lexy J. Moleong, 2004, Metodologi Penelitian Kualitatif, Bandung: Remaja Rosdakarya

Masidjo, 1995, Penilaian Pencapaian Hasil Belajar, Yogyakarta: Kanisius.

Peraturan Menteri Pendidikan dan Kebudayaan Nomor 64 Tahun 2013 tentang standar isi pendidikan dasar dan menengah

Peraturan menteri pendidikan dan kebudayaan Republik Indonesia
Nomor 104 tahun 2014 Tentang Penilaian hasil belajar oleh pendidik Pada pendidikan dasar dan pendidikan menengah.

Peraturan menteri pendidikan dan kebudayaan Republik Indonesia Nomor 23 tahun 2016 Tentang Standar Penilaian pendidikan.

Peraturan Mentri Pendidikan Nasional R.I Nomor 22 tahun 2006 tentang Standar Isi Untuk Satuan Pendidikan Dasar dan Menengah. 